\title{
KONSEP PENDIDIKAN DALAM ALQURAN (Sebuah Kajian Tematik)
}

\author{
Hamzah Djunaid \\ Dosen UIN Alauddin Makassar DPK pada UIM Makassar \\ Telp. (0411)8214982/08114105356 \\ Email: hamzah_djunaid@yahoo.com
}

\begin{abstract}
Abstrak:
Istilah pendidikan dalam bahasa Arab, biasa diterjemahkan dengan isitilah, seperti; tarbiyah dan ta'lim dengan berbagai derivasinya. Kedua istilah tersebut terdapat di beberapa tempat dalam al-Quran dengan berbagai konteks yang berbeda-beda. Untuk mengkaji masalah ini, digunakan pendekatan tematik (maudhu'i) dengan meneliti ayat-ayat yang berhubungan dengan pendidikan. Dari hasil kajian ini dapat disimpulkan bahwa konsep tarbiyah dan ta'lim adalah proses pembinaan, pengembangan, dan pemeliharaan serta pemberian bekal berupa ilmu pengetahuan dan keterampilan kepada peserta didik agar mereka memiliki kepribadian dan sikap mental yang luhur, sehingga mampu melaksanakan tugasnya sebagai khalifah Allah di muka bumi ini sesuai dengan daya nalar masing-masing.
\end{abstract}

\begin{abstract}
:
The term education in Arabic is usually translated into the terms tarbiyah and ta'lim with their various derivations. Both of the terms can be found in many places in Al-Quran and with many different context. To study this problem, thematic approach (maudhu'i) was used. Based on this study, it can be concluded that the concept of tarbiyah and ta'lim are the process of educating, developing, maintaining, and also teaching knowledge and skills to students in order that they can have a good personality and good mental attitude to perform their duty as the khalifah of Allah in the earth.
\end{abstract}

Kata kunci:

Pendidikan, al-Qur'an, Tematik

\begin{abstract}
AL-QUR'AN merupakan firman Allah yang dijadikan pedoman hidup (way of life) oleh kaum muslim yang tidak ada keraguan di dalamnya. Al-Qur'an mengandung ajaran-ajaran pokok (prinsip dasar) menyangkut segala aspek kehidupan manusia dan dalam berbagai permasalahannya. Al-Qur'an bagaikan sumber mata air yang tidak pernah kering ketika manusia mengambil dan mengkaji hikmah isi kandungannya. Sudah tentu tergantung kemampuan dan daya nalar setiap orang dan kapan pun masanya akan selalu hadir secara fungsional memecahkan problem kemanusiaan.

Salah satu permasalahan yang tidak sepi dari perbincangan umat adalah masalah pendidikan. Al-Qur'an sendiri telah memberi isyarat bahwa permasalahan pendidikan sangat penting. Jika al-Qur'an dikaji lebih mendalam, akan ditemukan beberapa prinsip dasar pendidikan yang dijadikan sumber inspirasi untuk dikembangkan dalam rangka membangun pendidikan yang bermutu.
\end{abstract}


Ada beberapa indikasi yang terdapat dalam al-Qur'an yang berkaitan dengan pendidikan antara lain; pertama, al-Qur'an sangat menghormati akal manusia. Harun Nasution menjelaskan bahwa ada tujuh kata yang digunakan al-Qur'an untuk menunjukkan pentingnya akal yaitu kata nazara (QS al-Qaaf/50: 6-7, al-Thaariq/86 : 5-7, al-Ghasiyah/88: 17-20), kata tadabbara (QS Shaad/38: 29, Muhammad/47: 24), kata tafakkara (QS al-Nahl/16: 68-69, al-Jasiyah/45: 12-13), kata faqiha (QS al-An'am/6: 25, 65, dan 98; al-A'raf/7: 179), kata tadzakkara (antara lain QS al-Baqarah/2: 221, 235, dan 282; al-An'am/6: 80, 152), kata fahima (antara lain QS an-Nisa/4: 78; al-An'am/6: 25 dan 65), dan kata aqala (antara lain QS al-Baqarah/2: 73-76, Ali Imran/3: 65 dan 118). ${ }^{1}$ Menurut Syahidin, kata 'aqala disebut di dalam al Qur'an sebanyak 49 ayat, dan kata lain yang digunakan al-Qur'an untuk memaknai 'aqala adalah al-Albab dan Uly alNuha. ${ }^{2}$ Abdul Fattah Jalal juga menjelaskan bahwa kata 'aqala di dalam al-Qur'an kebanyakan digunakan dalam bentuk fiil (kata kerja) dan hanya sedikit dalam bentuk ism (kata benda). Itu menunjukkan bahwa pada akal, yang penting berpikir bukan akal sebagai otak yang berupa benda. ${ }^{3}$ Kedua, al-Qur'an sangat menghargai ilmu pengetahuan dan orang yang berilmu pengetahuan. Al-Qur'an berkali-kali menjelaskan pentingnya pengetahuan. Tanpa pengetahuan, niscaya kehidupan manusia akan menjadi sengsara. Al-Qur'an memperingatkan manusia agar mencari ilmu pengetahuan sebagaimana firman Allah dalam QS al-Taubah/9: 122 disebutkan:

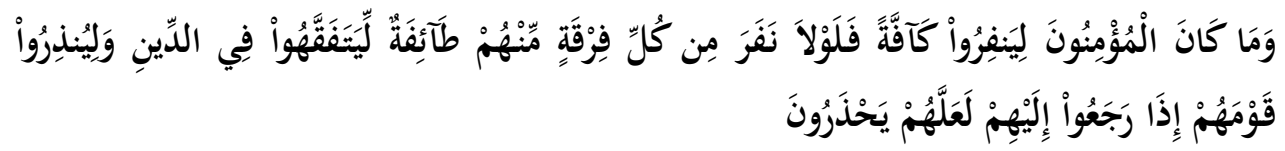

Terjemahnya:

Mengapa tidak pergi dari tiap-tiap golongan di antara mereka beberapa orang untuk memperdalam pengetahuan mereka tentang agama dan untuk memberi peringatan kepada kaumnya apabila mereka telah kembali kepadanya, supaya mereka itu dapat menjaga dirinya. ${ }^{4}$

Dari sini dapat dipahami bahwa betapa pentingnya pengetahuan bagi kelangsungan hidup manusia. Dengan pengetahuan, manusia akan mengetahui apa yang baik dan yang buruk, yang benar dan yang salah, yang membawa manfaat dan yang membawa madarat. Tidak hanya itu, bahkan al-Qur'an memposisikan manusia yang memiliki pengetahuan pada derajat yang tinggi. al-Qur'an surat al-Mujadalah/58: 11 menyebutkan:

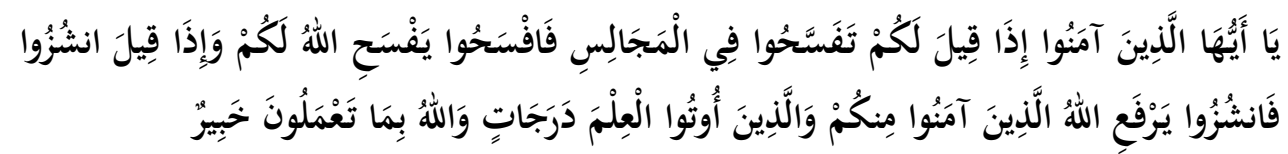

Terjemahnya:

Wahai orang-orang yang beriman! Apabila dikatakan kepadamu, Berilah kelapangan di dalam majelis-majelis, maka lapangkanlah, niscaya Allah akan Memberi kelapangan untukmu. Dan apabila dikatakan, Berdirilah kamu, maka berdirilah, niscaya Allah akan Mengangkat (derajat) orang-orang yang beriman 
di antaramu dan orang-orang yang diberi ilmu beberapa derajat. Dan Allah Maha

Teliti apa yang kamu kerjakan. ${ }^{5}$

Ayat tersebut menunjukkan bahwa orang yang beriman dan berilmu pengetahuan diangkat derajatnya oleh Allah swt. beberapa derajat. Derajat yang dimaksudkan dapat bermakna kedudukan, kelebihan atau keutamaan dari makhluk lainnya, dan hanya Allah swt. yang lebih mengetahuinya tentang bentuk dan jenisnya serta kepada siapa yang akan ditinggikan derajatnya.

Mengingat masalah yang berhubungan dengan pendidikan menurut al-Qur'an meliputi berbagai masalah, maka dalam tulisan ini akan dibatasi dengan mengangkat fokus pembahasan meliputi: pengertian dan tujuan pendidikan menurut al Qur'an serta metode-metode pendidikan menurut al-Qur'an.

\section{PEMBAHASAN}

\section{Pengertian Pendidikan Menurut al-Qur'an}

Ada dua kata yang digunakan al-Qur'an untuk mengungkapkan makna pendidikan yaitu kata rabb dengan bentuk masdarnya tarbiyah dan kata 'allama dengan bentuk masdarnya ta'lim. Kata tarbiyah sebagaimana dijelaskan oleh al-Raghib alAshfahany adalah sya'a al-syai halan fa halun ila haddi al-tamam; artinya mengembangkan atau menumbuhkan sesuatu setahap demi setahap sampai batas yang sempurna. Sedangkan kata ta'lim digunakan secara khusus untuk menunjukkan sesuatu yang dapat diulang dan diperbanyak sehingga menghasilkan bekas atau pengaruh pada diri seseorang. ${ }^{6}$

Kata rabb dengan segala derivasinya disebutkan dalam al-Qur'an sebanyak 981 kali. ${ }^{7}$ Kata tersebut selanjutnya digunakan oleh al-Qur'an untuk berbagai makna antara lain digunakan untuk menerangkan salah satu sifat Allah swt. yaitu rabbul 'alamin yang diartikan pemelihara, pendidik, penjaga, dan penguasa alam semesta (lihat QS al- Fatihah/1: 2, al-Baqarah/2: 131, al-Maidah/5: 28, al-An'am/6: 45, 71, 162, dan 164, al-A'raf/7: 54, digunakan juga untuk menjelaskan objek sifat tuhan sebagai pemelihara, pendidik, penjaga, dan penguasa alam semesta seperti: al-'arsy al-'azhim yakni 'arsy yang agung (QS al-Taubah/9: 129), al-Masyariq, yakni ufuk timur tempat terbitnya matahari (al-Rahman/55: 17), abaukum al-awwalun yakni nenek moyang para pendahulu orang-orang kafir Quraisy (QS al-Shaffat/37: 126), al-Baldah, yakni negeri dalam hal ini Mekah al-Mukarramah (QS al-Naml/27: 91; al-Baqarah/2: 126), al-Bait yakni rumah, dalam hal ini Ka'bah yang ada di Mekah al-Mukarramah (QS Quraisy/106: 3) dan al-Falaq yakni waktu subuh (QS al-Falaq/112: 1).

Berdasarkan makna-makna tersebut di atas, terlihat dengan jelas bahwa kata rabb dalam al-Qur'an digunakan untuk menunjukkan obyek yang bermacam-macam, baik fisik maupun non fisik. Dengan demikian, pendidikan oleh Allah swt. meliputi pemeliharaan seluruh makhluk-Nya.

Adapun kata 'allama dengan segala bentuk derivasinya disebutkan dalam alQur'an sebanyak 854 kali, ${ }^{8}$ dan digunakan dalam berbagai konteks. Terkadang digunakan untuk menjelaskan bahwa Allah sebagai subyek yang mengajarkan kepada 
manusia beberapa hal antara lain: mengajarkan nama-nama (benda) semuanya (surat al-Baqarah/2: 31-32), mengajarkan al-Qur'an (SQ. Ar-Rahman/55: 1-4), mengajarkan al-hikmah, taurat, dan injil (QS Ali-Imran/3: 48) mengajarkan kepada manusia apa yang tidak diketahui (QS al-Alaq/96: 5 dan QS al-Baqarah/2: 239) dan terkadang digunakan bahwa manusia sebagai subyek, seperti Nabi Musa mengajarkan sihir kepada pengikut Fir'aun (al-Syu'ara/26: 49 dan QS Thaha/20: 71) dan terkadang pula digunakan bahwa Jibril sebagai subyek yang mengajarkan wahyu kepada Nabi Muhammad saw. (QS An-Najm/53: 5). Dari beberapa ungkapan tersebut, terkesan bahwa kata ta'lim dalam al-Qur'an menunjukkan adanya sesuatu berupa pengetahuan yang diberikan kepada seseorang. Jadi, sifatnya intelektual.

Dalam pembahasan selanjutnya ditemukan perbedaan pendapat di kalangan para ahli mengenai pemakaian kata tersebut dalam hubungannya dengan pendidikan. Menurut Abdurrahman al-Nahlawi dalam Ahmad Tafsir, bahwa kata tarbiyah lebih tepat digunakan untuk makna pendidikan. Menurutnya, kata Tarbiyah' berasal dari tiga kata, yaitu: pertama, dari kata raba-yarbu yang berarti bertambah atau tumbuh; karena pendidikan mengandung misi untuk menambah bekal pengetahuan kepada anak dan menumbuhkan potensi yang dimilikinya. Kedua, dari kata rabiyayarba' yang berarti menjadi besar, karena pendidikan juga mengandung misi untuk membesarkan jiwa dan memperluas wawasan seseorang. Ketiga, dari kata rabbayarubbu' yang berarti memperbaiki, menguasai urusan, menuntun, menjaga, memelihara sebagaimana telah dijelaskan di atas. ${ }^{9}$

Berbeda dengan pendapat di atas, Abdul Fattah Jalal mengatakan bahwa kata ta'lim lebih komprehensif untuk mewakili istilah pendidikan karena kata tersebut berhubungan dengan tiga aspek. Pertama, menyangkut aspek pemberian bekal pengetahuan, pemahaman, pengertian, tanggung jawab, dan penanaman amanah, hingga penyucian atau pembersihan manusia dari segala kotoran dan menjadikan diri manusia berada dalam kondisi yang memungkinkan untuk menerima al-hikmah serta mempelajari apa yang bermanfaat baginya dan yang tidak diketahuinya. Kedua, menyangkut aspek pengetahuan dan keterampilan yang dibutuhkan seseorang dalam hidup serta pedoman perilaku yang baik. Ketiga, merupakan proses yang terus menerus diusahakan semenjak dilahirkan, sebab menusia dilahirkan tidak mengetahui apa-apa, tetapi dia dibekali dengan berbagai potensi yang mempersiapkannya untuk meraih dan memahami ilmu pengetahuan serta memanfaatkanya dalam kehidupan. ${ }^{10}$

Sedangkan menurut Sayed Muhammad al-Naquid al-Atas, kata at-ta'lim disinonimkan dengan pengajaran tanpa adanya pengenalan secara mendasar, namun bila al-ta'lim disinonimkan dengan al-tarbiyah, al-ta'lim mempunyai arti pengenalan tempat segala sesuatu dalam sebuah sistem. Menurutnya, ada hal yang membedakan antara tarbiyah dan ta'lim, yaitu ruang lingkup ta'lim lebih umum daripada tarbiyah, karena tarbiyah tidak mencakup segi pengetahuan dan hanya mengacu pada kondisi eksistensial dan juga tarbiyah merupakan terjemahan dari bahasa latin education, yang keduanya mengacu kepada segala sesuatu yang bersifat fisik-mental, tetapi sumbernya bukan dari wahyu. ${ }^{11}$ 
Kebalikan dari pendapat Sayed Muhammad al-Naquid al-Atas, Muhammad Athiyah al-Abrasy, mengatakan bahwa kata ta'lim lebih khusus dibandingkan dengan tarbiyah. Hal itu karena kata ta'lim hanya merupakan upaya menyiapkan individu dengan mengacu pada aspek-aspek tertentu saja, sedangkan kata tarbiyah mencakup keseluruhan aspek-aspek pendidikan.12 Sementara itu Abuddin Nata mengatakan bahwa istilah $\mathrm{ta}^{\prime} \mathrm{lim}$ mengesankan proses pemberian bekal pengetahuan, sedangkan istilah tarbiyah mengesankan proses pembinaan dan pengarahan bagi pembentukan kepribadian dan sikap mental. ${ }^{13}$

Berdasarkan beberapa pengertian di atas dapat di simpulkan bahwa pendidikan menurut al-Qur'an adalah usaha yang dilakukan secara terencana dan bertahap untuk memberikan pengetahuan, keterampilan, dan sikap kepada peserta didik sebagai bekal dalam melaksanakan tugasnya sebagai hamba dan khalifah Allah di muka bumi.

\section{Tujuan Pendidikan Menurut al-Qur'an}

Pendidikan sebagai upaya untuk membantu manusia dalam melaksankan tugasnya sebagai hamba dan khalifah Allah di muka bumi, maka ada 4 ayat yang dapat dijadikan rujukan untuk merumuskan tujuan pendidikan menurut al-Qur'an yaitu:

1. QS Al-Dzariyaat/51: 56

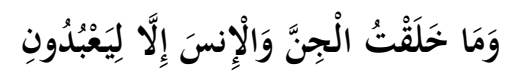

Terjemahnya:

Aku tidak menciptakan jin dan manusia melainkan agar mereka beribadah kepada-Ku. ${ }^{14}$

Menurut Sayyid Quthub, meskipun ayat di atas sangat singkat namun mengandung hakekat yang besar dan agung. Manusia tidak akan berhasil dalam hidupnya tanpa menyadari maknanya dan menyadarinya, baik kehidupan pribadi maupun kolektif. Ayat ini menurutnya membuka sekian banyak sisi dan aneka sudut dan tujuan. Sisi pertama bahwa pada hakekatnya ada tujuan tertentu dari wujud manusia dan jin. Ia merupakan satu tugas. Siapa yang melaksanakannya, maka dia telah mewujudkan tujuan wujudnya, dan siapa yang mengabaikannya maka dia telah membatalkan hakekat wujudnya dan menjadilah dia sesorang yang tidak memiliki tugas (pekerjaan), hidupnya kosong tidak bertujuan dan berakhir dengan kehampaan. Tugas tersebut adalah ibadah kepada Allah yakni penghambaan diri kepada-Nya. Menurutnya, pengertian ibadah bukan hanya terbatas pada pelaksanaan tuntunan ritual, karena jin dan manusia tidak menghabiskan waktu mereka dalam pelaksanaan ibadah ritual. Allah tidak hanya mewajibkan mereka melakukan hal tersebut, tetapi Allah mewajibkan aneka kegiatan yang lain yang menyita sebagian besar hidupnya.

Aneka kegiatan yang dimaksud tidak lain adalah tugas kekhalifahan yakni memakmurkan bumi, mengenal potensinya, perbendaharaan yang terpendam di dalamnya, sambil mewujudkan apa yang dikehendaki Allah dalam penggunaan, pengembangan, dan peningkatannya. Kekhalifahan juga menuntut upaya penegakan syariat 
Allah di bumi dan mewujudkan sistem ilahi yang ditetapkannya bagi alam raya ini. Dengan demikian, ibadah yang dimaksud di sini lebih luas jangkauan maknanya dari pada ibadah dalam bentuk ritual. Tugas khalifahan termasuk dalam makna ibadah.

Menurut M. Quraish Shihab, hakekat ibadah dalam ayat tersebut mencakup dua hal pokok: Pertama, kemantapan makna penghambaan diri kepada Allah dalam hati setiap insan. Kemantapan perasaan bahwa ada hamba dan ada Tuhan, hamba yang patuh dan Tuhan yang dipatuhi (disembah). Tidak selainnya. Tidak ada dalam wujud ini kecuali satu Tuhan dan selainnya adalah hamba-hamba-Nya. Kedua, mengarah kepada Allah dengan setiap gerak pada nurani, pada setiap anggota badan, dan setiap gerak dalam hidup. Semuanya hanya mengarah kepada Allah secara tulus. Melepaskan diri dari segala perasaan yang lain dan segala makna selain makna penghambaan diri kepada Allah. ${ }^{15}$

Pertanyaannya kemudian apakah manusia serta merta mampu melaksanakan tugasnya sebagai hamba tanpa bimbingan atau pendidikan? Di sinilah pentingnya pendidikan bagi manusia. Oleh karena itu, salah satu tujuan pendidikan yang dapat dipahami dari al-Qur'an adalah membimbing dan mengantar menusia untuk melaksanakan tugasnya sebagai hamba Allah swt.

2. QS Al-Baqarah/2: 31

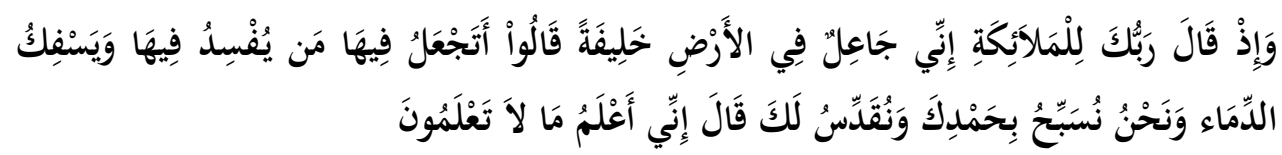

Terjemahnya:

Dan (ingatlah) ketika Tuhan-mu Berfirman kepada para malaikat, Aku hendak menjadikan khalifah di bumi." Mereka berkata, Apakah Engkau hendak menjadikan orang yang merusak dan menumpahkan darah di sana, sedangkan kami bertasbih memuji-Mu dan menyucikan nama-Mu? Dia berfirman, Sungguh, Aku mengetahui apa yang tidak kamu ketahui. ${ }^{16}$

Dari ayat di atas dipahami bahwa Allah swt. menciptakan manusia sebagai khalifah di muka bumi. Kata khalifah pada mulanya berarti yang menggantikan atau yang datang sesudah siapa yang datang sebelumnya. Selanjutnya khalifah dipahami sebagai yang menggantikan Allah dalam menegakkan kehendak-Nya dan menerapkan ketetapan-ketetapan-Nya. ${ }^{17}$ Ada empat sisi yang terkandung dalam tugas kekhalifahan yang saling berkaitan yaitu: (1) pemberi tugas, dalam hal ini Allah swt.; (2) penerima tugas, dalam hal ini manusia; (3) tempat atau lingkungan di mana manusia berada, dalam hal ini bumi; dan (4) materi-materi penugasan yang harus dilaksanakan, dalam hal ini memakmurkan bumi.

Tugas khalifah tidak akan dinilai berhasil apabila materi penugasan tidak dilaksanakan atau apabila kaitan antara penerima tugas dan lingkungannya tidak diperhatikan. Untuk dapat melaksanakan tugasnya sebagai khalifah, manusia membutuhkan pembinaan dan pendidikan. Atau dengan kata lain pendidikan harus mampu membantu manusia dalam melaksanakan sebagai khalifah. 
3. QS Al-Hujurat/49: 13:

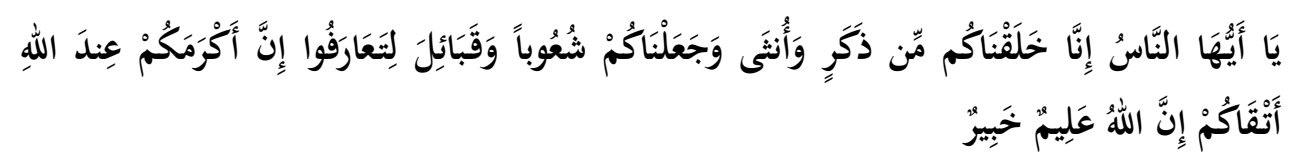

Terjemahnya:

Wahai manusia! Sungguh, Kami telah Menciptakan kamu dari seorang laki-laki dan seorang perempuan, kemudian Kami Jadikan kamu berbangsa-bangsa dan bersuku-suku agar kamu saling mengenal. Sungguh, yang paling mulia di antara kamu di sisi Allah ialah orang yang paling bertakwa. Sungguh, Allah Maha Mengetahui, Maha teliti. ${ }^{18}$

Salah satu makna yang dapat dipahami dari ayat di atas adalah bahwa manusia yang paling mulia di sisi Allah swt. adalah manusia yang paling bertakwa, yaitu manusia yang senantiasa melaksanakan segala perintah Allah, baik perintah yang berkaitan dengan tugas kehambaan maupun yang berkaitan dengan tugas khalifahan dan menjauhi segala larangan-Nya. Dengan demikian, tujuan pendidikan menurut alQur'an adalah membina manusia sehingga mampu menjalankan fungsinya sebagai hamba Allah dan khalifah-Nya guna membangun dunia ini sesuai dengan konsep yang di tetapkan oleh Allah atau dengan kata lain menjadikan manusia bertakwa kepada Allah swt.

Uraian di atas, sejalan dengan rumusan tujuan pendidikan yang dikemukakan oleh beberapa tokoh pendidikan Islam sebagaimana yang ditulis oleh Ahmad Tafsir antara lain: Al-Attas merumuskan tujuan pendidikan Islam adalah terbentuknya manusia yang baik. Sedang Abdul Fattah Jalal merumuskan bahwa tujuan pendidikan Islam adalah terwujudnya manusia sebagai hamba Allah. Demikian pula Sayyed Qutub mengemukakan tujuan pendidikan Islam adalah manusia yang takwa. Sedang menurut Komprensi Dunia Islam pertama 1977 berkesimpulan bahwa tujuan akhir pendidikan Islam adalah manusia yang menyerahkan diri secara mutlak kepada Allah. ${ }^{19}$

Rumusan tujuan pendidikan tersebut, dari segi redaksinya berbeda, namun mempunyai esensi dan kandungan yang sama. Yaitu sama-sama menyatakan bahwa tujuan pendidikan ialah membentuk kepribadian seorang muslim yang dilandasi keimanan dan ketakwaan sehingga dapat menjadi insan muslim yang sempurna (insan kamil ).

\section{Metode Pendidikan Menurut Al-Qur'an}

Secara tersurat tidak ditemukan ayat- ayat al-Qur'an yang menjelaskan tentang metode pendidikan. Namun, jika dianalisis dari segi redaksi al-Qur'an dan cara Allah mengajarkan ajaran-ajaran-Nya kepada Rasul-rasul-Nya, ada beberapa metode yang dapat diadopsi menjadi metode pendidikan antara lain:

\section{Metode Dialog}

Ada beberapa ayat al-Qur' an yang disampaikan dengan cara dialog, baik dialog antara Allah dengan makhluk-Nya maupun dialog antara makhluk dengan makhluk 
lainnya. Dialog antara Allah dengan makhluk-Nya dapat dilihat ketika Allah hendak menciptakan manusia sebagai khalifah di muka bumi, Allah berdialog dengan malaikat, sebagaimana diungkapkan dalam QS al-Baqarah/2: 31.20 Demikian juga dialog antara Allah dengan penghuni neraka yang digambarkan dalam ayat QS alShaffat/37: 20-23.21 Adapun dialog antara makhluk dengan makhluk lainnya antara lain; dialog antara Nabi Syuaib dengan kaumnya sebagaimana disebutkan dalam QS Hud/11: 84-95.22 Demikian juga dialog antara Nabi Musa dengan Nabi Khaidir sebagaimana dikisahkan di dalam QS al-Kahfi/18: 65- 72.23

Dari ayat-ayat tersebut di atas terlihat dengan jelas bahwa Allah swt. Menggunakan metode dialog dalam menyampaikan ajaran-ajaran-Nya. Hal ini menjadi petunjuk bahwa metode seperti itu dapat digunakan dalam kegiatan pembelajaran. Menurut Ahmad Tafsir, metode dialog mempunyai dampak yang dalam bagi pembicara dan juga bagi pendengar pembicaraan itu. Itu disebabkan oleh beberapa hal sebagai berikut: Pertama, dialog itu berlangsung secara dinamis karena kedua pihak terlibat langsung dalam pembicaraan dan tidak membosankan. Kedua, pendengar tertarik untuk mengikuti terus pembicaraan itu karena ia ingin tahu kesimpulannya. Ketiga, dapat membangkitkan perasaan dan menimbulkan kesan dalam jiwa, yang membantu mengarahkan seseorang menemukan sendiri kesimpulannya. Keempat, bila dialog dilakukan dengan baik, memenuhi akhlak tuntunan Islam, akan meninggalkan pengaruh berupa pendidikan akhlak dalam berbicara. ${ }^{24}$

\section{Metode Kisah}

Al-Qur'an menyampaikan pesan-pesannya juga menggunakan metode kisah. Di dalam al-Qur'an di temukan sejumlah ayat yang berisi tentang kisah-kisah umat terdahulu. Kisah al-Qur'an banyak ragam dan bentuknya. Al-Qaththan membagi kisah dalam tiga bentuk. ${ }^{25}$

Pertama, kisah-kisah tentang nabi-nabi terdahulu. Al-Qur'an mengungkapkan upaya dakwah yang dilakukan nabi terdahulu, kejadian dan peristiwa yang termasuk mukjizat yang diberikan Allah kepada mereka, sikap-sikap perlawanan dari kaum mereka, pertumbuhan dakwah, dan balasan bagi orang yang percaya (mukmin) dan mengingkari (mukadzdzib) dakwah para nabi. Di antara contoh kisah para nabi terdahulu adalah kisah Nabi Nuh dengan perahu penyelamat dan anaknya yang durhaka, kisah keteguhan Nabi Ibrahim melawan pejabat yang zalim, bahkan terhadap orang tuanya sendiri yang tidak mau beriman kepada Allah. Juga kisah Nabi Musa dengan kaummnya yang 'ngeyel', kisah Nabi Harun, kisah perjuangan Nabi Isa, dan bahkan kisah perjuangan Nabi Muhammad sendiri. Selain itu, adapula kisah Nabi Ismail, Nabi Ya'kub, dan nabi-nabi lainnya.

Kedua, kisah-kisah tentang peristiwa masa lalu dan kisah tentang orang-orang tertentu yang tidak ditetapkan status kenabiannya. Sebagai contoh al-Qur'an mengisahkan keluarnya ribuan orang dari rumahnya karena takut akan kematian. Adapula kisah seseorang yang dijuluki al-Qur'an dengan Thalut dan Jalut, kisah dua anak Adam, Qabil dan Habil. Al-Qur'an juga menceritakan keluarga Kahfi, Dzul Qarnain, Qarun, Ashhab al-Sabt, Maryam, Asbab al-Ukhdud, Ashhab al-Fil. 
Ketiga, kisah-kisah tentang peristiwa yang terjadi pada masa Nabi Muhammad. Sebagai contoh cerita tentang peperangan Badar dan Uhud yang disebutkan dalam surat Ali Imran, perang Hunain dan Tabuk yang dipaparkan dalam surat al-Taubah, perang Ahzab diceritakan dalam surat al-Ahzab. Adapula kisah tentang isra' dan mi'raj Nabi Muhammad di bulan Ramadhan, kisah hijrah Nabi ke Madinah, dan kisah-kisah lainnya. Kisah-kisah al-Qur'an tersebut di atas menunjukkan cara Allah swt. untuk mendidik hamba-hamba-Nya agar beriman kepada-Nya. Ada beberapa kelebihan yang dapat diambil dari metode kisah al-Qur'an sebagai berikut. ${ }^{26}$

Pertama, kisah al-Qur'an selalu memikat karena mengundang pembaca atau pendengar untuk mengikuti peristiwanya dan merenungkan maknanya. Selanjutnya makna-makna itu akan menimbulkan kesan dalam hati pembaca atau pendengar tersebut. Kedua, kisah al-Qur'an dapat menyentuh hati manusia karena kisah itu menampilkan tokoh dalam konteksnya yang menyeluruh sehingga pembaca atau pendengar dapat ikut menghayati atau merasakan isi kisah itu, seolah-olah ia sendiri yang menjadi tokohnya. Ketiga, kisah al-Qur'an mendidik perasaan keimanan dengan cara: 1) membangkitkan berbagai perasaan seperti khauf, rida, dan cinta, 2) mengarahkan seluruh perasaan sehingga bertumpu pada suatu puncak yaitu kesimpulan kisah, dan 3) melibatkan pembaca atau pendengar ke dalam kisah tersebut, sehingga ia terlibat secara emosional.

\section{Metode Amtsal (Perumpamaan)}

Adakalanya Allah swt. mengajari hamba-hamba-Nya dengan membuat perumpamaan-perumpamaan. Ada beberapa perumpamaan yang ditemukan dalam alQur'an, sebagaimana digambarkan dalam al-Qur'a Surah Al-Baqarah/2: 17, Surah AlBaqarah/2: 171, Perumpamaan (nafkah yang dikeluarkan oleh) orang-orang yang menafkahkan hartanya di jalan Allah QS al-Baqarah/2: 261, ${ }^{27}$ dan perumpamaan surga yang dijanjikan kepada orang-orang yang takwa QS Al-Ra'du/13: 35,28 Perumpamaan kalimat yang baik adalah seperti pohon yang baik, akarnya teguh dan cabangnya (menjulang) ke langit, dan perumpamaan kalimat yang buruk seperti pohon yang buruk, yang telah dicabut dengan akar-akarnya dari permukaan bumi; tidak dapat tetap (tegak) sedikit pun. (QS Ibrahim/14: 24 \& 26,29 dan perumpamaan cahaya Allah adalah seperti sebuah lubang yang tak tembus, yang di dalamnya ada pelita besar QS Al-Nuur, 24:35,30 serta perumpamaan orang-orang yang mengambil pelindung-pelindung selain Allah adalah seperti laba-laba yang membuat rumah. Dan sesungguhnya rumah yang paling lemah ialah rumah laba-laba kalau mereka mengetahui. (QS Al-'Ankabut/29: 41). ${ }^{31}$

Dari uraian di atas terlihat dengan jelas bahwa Allah swt. menggunakan perumpamaan-perumpamaan dalam menyampaikan ajaran-ajaran-Nya. Hal ini menjadi petunjuk bahwa cara seperti itu dapat juga digunakan dalam kegiatan pembelajaran. Sedikitnya ada dua kelebihan yang dapat diperoleh dengan menggunakan metode ini; pertama, mempermudah peserta didik memahami konsep yang abstrak. Ini terjadi karena perumpamaan itu mengambil benda kongkrit; kedua, dapat merangsang kesan yang tersirat dari perumpamaan tersebut. 


\section{Metode Keteladanan}

Untuk memudahkan pemahaman dan pelaksanaan ajaran-ajaran yang diturunkan kepada hamba-hamba-Nya maka Allah swt. menyebutkan beberapa tokoh yang dapat dijadikan teladan antara lain: 1) Keteladanan para Nabi, dapat dilihat dalam QS al-An'am/6: 90.32 2) Keteladanan Nabi Ibrahim as. dan umatnya, digambarkan dalam QS al-Mumtahanah/60: 4 dan 6.33 3) Keteladanan Nabi Muhammad saw., dijelaskan dalam QS al-Ahzab/33: 21.34 4) Keteladanan orang-orang yang pertama-tama masuk Islam, dijelaskan dalam QS al-Taubah/9: 100.35 dan 5)Keteladanan orang- orang yang beriman, hal ini dapat dilihat pada QS al-Thur/52: 21. ${ }^{36}$

Keteladanan tokoh-tokoh yang disebutkan di atas merupakan kunci kesuksesan mereka dalam mengembang tugas-tugas mereka yang diberikan oleh Allah swt. Dalam dunia pendidikan, keteladanan merupakan unsur yang sangat penting. Peserta didik cenderung meneladani pendidiknya. Hal ini diakui oleh semua ahli pendidikan, baik dari barat maupun timur. Dasarnya ialah bahwa secara psikologis anak memang senang meniru, tidak saja yang baik, yang jelek pun ditirunya.

\section{Metode Targhib dan Tarhib}

Targhib ialah janji terhadap kesenangan, kenikmatan di akhirat yang disertai bujukan. Tarhib ialah ancaman karena dosa atau pelanggaran yang dilakukan. Targhib dan tarhib bertujuan agar manusia mematuhi aturan Allah. ${ }^{37}$ Selanjutnya di dalam alQur'an ditemukan sekitar $300 .{ }^{38}$ ayat yang berisi tentang targhib dan tarhib antara lain: a. Ayat-ayat yang berisi targhib dapat dilihat dalam QS al-Baqarah/2: 25, QS Ali Imran/3: 57, QS al-Nisaa/4: 175, QS al-Taubah/9: 88-89.39

b. Ayat-ayat yang berisi metode tarhib, dapat dilihat pula dalam QS al-An'am/6: 147 dan dalam QS al-A'raf/7: 95, al-Anfaal/8: 25, dan QS al-Taubah/9: 17.40

Contoh- contoh di atas menunjukkan bahwa salah satu cara Allah untuk memotivasi hamba-hamba-Nya dalam melaksanakan ajaran-ajaran-Nya sekaligus mencegah mereka untuk melanggar larang-larangan-Nya, adalah dengan menggunakan metode targhib dan tarhib. Di dalam proses pembelajaran, motivasi merupakan faktor yang sangat menentukan keberhasil pembelajaran. Oleh karena itu, pendidik harus mampu membangkitkan motivasi peserta didiknya. Salah satu caranya adalah dengan memberikan penghargaan kepada peserta didik yang rajin dan bersungguhsungguh serta memberikan sanksi bagi peserta didik yang malas.

\section{SIMPULAN}

Al-Qur'an mengungkapkan istilah pendidikan dengan kata tarbiyah dan taklim. Kata tarbiyah digunakan untuk makna yang lebih luas yaitu proses pembinaan dan pengarahan bagi pembentukan kepribadian dan sikap mental sedangkan kata taklim digunakan untuk makna yang lebih khusus yakni proses pemberian bekal berupa pengetahuan dan ketermpilan. Berdasarkan kedua istilah tersebut maka pendidikan menurut al-Qur'an dirumuskan sebagai usaha yang dilakukan secara terencana dan bertahap untuk memberikan pengetahuan, keterampilan, dan sikap mental 
kepada peserta didik sebagai bekal dalam melaksanakan tugasnya sebagai hamba dan khalifah Allah di muka bumi.

Tujuan pendidikan menurut al-Qur'an adalah membina manusia sehingga mampu menjalankan fungsinya sebagai hamba Allah dan khalifah-Nya guna membangun dunia ini sesuai dengan konsep yang di tetapkan oleh Allah atau dengan kata lain menjadikan manusia bertakwa kepada Allah swt.

Ada beberapa metode di dalam al-Qur'an yang dipergunakan oleh Allah swt. untuk menyampaikan ajaran-ajaran-Nya kepada hamba-hamba-Nya yang dapat diadopsi menjadi metode pendidikan antara lain; metode dialog, metode kisah, metode perumpamaan, metode keteladanan, serta metode targhib dan tarhib.

\section{CATATAN AKHIR:}

1. Harun Nasution, Akal dan Wahyu dalam Islam, Jakarta:Universitas Indonesia: 1982, h. 39-48.

2. Syahidin, Menelusuri Metode Pendidikan dalam Al Qur'an, Bandung: Alfabeta, 2009, h. 65.

3. Abdul Fattah Jalal, Azas-azas Pendidikan Islam, terj. Herry Noer, Bandung: Diponegoro, 1988, h.57-58

4. Departemen Agama RI, Al-Qur'an dan Tafsirnya, Edisi yang Disempurnakan, Jilid, 4 Jakarta: Departemen Agama, 2009, h. 231.

5. Ibid., h. 23.

6. Al-Raghib al-Ashfahany, Mu'jam Mufradat li Alfadz al-Qur'an, Bairut: Daār al-Fikr, t.t., h. 336.

7. Muhammad Zaki Muhammad Khadr, Mu'jam Kalimat al-Qur'an al-Karim, Juz 12, 2005, h. 3.

8. Ibid., Juz 20, h. 12.

9. Ahmad Tafsir, Ilmu Pendidikan dalam Perspektif Islam, Bandung: Rosdakarya, 2010, h. 29.

10. Abdul Fattah Jalal, Min al-Usuli al-Tarbawiyah fi al-Islam, Mesir: Darul Kutub Misriyah. 1977, h. 32.

11. Naquib al-Attas, Konsep Pendidikan dalam Islam, Bandung: Mizan, 1988, h. 17.

12. M. Athiyah al-Abrasy, Al-Tarbiyah al-Islamiyah, terj. Bustami A. Gani dan Djohar Bakry, Jakarta: Bulan Bintang, 1968, h. 32.

13. Abuddin Nata, Filsafat Pendidikan Islam, Jakarta: Logos Wacana Ilmu, 1997, h. 8.

14. Departemen Agama RI, op. cit., Jilid 9, h. 485.

15. M. Quraish Shihab, Tafsir Al-Mishbah, Jilid XIII, Jakarta: Lentera Hati, 2000, h. 360

16. Departemen Agama RI, op. cit., Jilid 1, h. 74

17. M. Quraish Shihab, Tafsir Al-Mishbah, Jilid I, h. 140.

18. Departemen Agama RI, op. cit., Jilid 9, h. 419.

19. Ahmad Tafsir, op. cit., h. 46-49.

20. Departemen Agama RI, op. cit., Jilid 1, h. 74.

21. Ibid., Jilid 8, h. 268.

22. Ibid., Jilid 4, h. 455-463.

23. Ibid., Jilid 5, h. 634-643.

24. Ahmad Tafsir, op. cit., h. 136.

25. Manna' al-Qaththan, Mabāhits fi 'Ulūm al-Qur'ān, Riyād: Mantsurāt al-'Ashr al-Hadīs, tt., h. 306.

26. Ahmad Tafsir, op. cit., h. 140-141.

27. Departemen Agama RI, op. cit., Jilid 1, h. 42, 247, 390. 
28. Ibid., Jilid 5, h. 112.

29. Ibid., Jilid 5, h. 143

30. Ibid., Jilid 6, h. 604

31. Ibid., Jilid 7, h. 404

32. Ibid., Jilid 3, h. 169.

33. Ibid., Jilid 10, h. 90.

34. Ibid., Jilid 7, h. 638

35. Ibid., Jilid 4, h. 192.

36. Ibid., Jilid 9, h. 504.

37. Ahmad Tafsir, op. cit., h. 146.

38. $h$ ttp://al-quran.bahagia.us/6/1/2012

39. Departemen Agama RI, op. cit., Jilid 1, h. 61. 517. Jilid, 2, h. 340, Jilid. 4, h. 173.

40. Ibid., Jilid 3, h. 260, 412, 596, Jilid; 4, h. 77.

\section{DAFTAR PUSTAKA}

Al-Abrasy, M. Athiyah. Al-Tarbiyah al-Islamiyah. Terj. Bustami A. Goni dan Djohar Bakry, Jakarta: Bulan Bintang, 1968.

Al-Ashfahany, Al-Raghib. Mu'jam Mufradat li Alfadz al-Qur'an. Bairut: Dar al-Fikr, t.t.

Al-Attas, Naquib. Konsep Pendidikan dalam Islam. Bandung: Mizan. 1988.

Departemen Agama RI. Al-Qur'an dan Tafsirnya. Jakarta: Departemen Agama, 2009.

Jalal, Abdul Fattah. Azas-azas Pendidikan Islam. Terj. Herry Noer, Bandung: Diponegoro, 1988.

Khadr, Muhammad Zaki Muhammad. Mu'jam Kalimat al-Qur'an al-Karim. Juz 12, 2005.

Nasution, Harun. Akal dan Wahyu dalam Islam. Jakarta: Universitas Indonesia, 1982.

Nata, Abuddin. Filsafat Pendidikan Islam. Jakarta: Logos Wacana Ilmu, 1997.

Qaththan, Manna'. Mabāhits fi 'Ulūm al-Qur'ān. Riyād: Mantsurāt al-'Ashr al-Hadīs, tt.

Shihab, M. Quraish. Tafsir Al-Mishbah. Jilid I, Jakarta: Lentera Hati, 2000.

Syahidin. Menelusuri Metode Pendidikan dalam al Qur'an. Bandung: Alfabeta, 2009.

Tafsir, Ahmad. Ilmu Pendidikan Dalam Perspektif Islam. Bandung: Rosdakarya, 2010. 